\title{
Effect of Voltage Gradient and Temperature on Electrical Conductivity of Grape (Vitis vinifera L.) Juice during Ohmic Heating
}

\author{
Tankesh Kumar $^{1 *}$, D.D. Smith ${ }^{2}$, Sivala Kumar ${ }^{1}$ and B. Vimla ${ }^{3}$ \\ ${ }^{1}$ Department of Processing and Food Engineering, ${ }^{2}$ Department of Food Engineering, \\ ${ }^{3}$ Department of Food and Industrial Microbiology, ANGRAU, Guntur, India \\ *Corresponding author
}

\section{A B S T R A C T}

\section{Keywords}

Ohmic heating, Grape juice, Voltage gradient,

Temperature, Electrical conductivity

Article Info

Accepted:

16 April 2018

Available Online:

10 May 2018
Ohmic heating is an alternative fast heating technique of foods. It is important to determine electrical conductivity in order to decide on the applicability of ohmic heating technology for specific food products. In this study, grape juice was heated at different voltage gradients $10,20,30$ and $40 \mathrm{~V} \mathrm{~cm}^{-1}$ holding at different temperature 55,6575 and $85{ }^{\circ} \mathrm{C}$ using a laboratory scale static ohmic heating system. The effect of voltage gradient and temperature on electrical conductivity of grape juice was investigated. Electrical conductivity of grape juice samples was $0.25-0.81 \mathrm{~S} \mathrm{~m}^{-1}$ at $10-40 \mathrm{~V} \mathrm{~cm}^{-1}$ and $30-85{ }^{\circ} \mathrm{C}$. The voltage gradient and temperature were statistically significant on the electrical conductivity for grape juice $(\mathrm{p}<0.05)$. As the voltage gradient was increased, electrical conductivity increased. The electrical conductivity of the sample linearly increased with temperature rise. The maximum EC of grape juice was found to be $0.81 \mathrm{~S} \mathrm{~m}^{-1}$ at $30 \mathrm{~V} \mathrm{~cm}^{-1}$ at $85{ }^{\circ} \mathrm{C}$. Bubbling was observed at higher voltage gradients $\left(40 \mathrm{~V} \mathrm{~cm}^{-1}\right)$ at higher temperature, especially above $75^{\circ} \mathrm{C}$.

\section{Introduction}

Grape (Vitis vinifera L.) is an important fruit of subtropical regions. It is known for its excellent flavour, colour, delicious taste and nutritional value. Grapes are very good source of copper, vitamin $\mathrm{B}_{1}, \mathrm{~B}_{2}$ and $\mathrm{K}$ (Rolle, 2011). Grape is one of the important commercial fruit crop in India. India holds $9^{\text {th }}$ rank in grapes production in the world. India's overall production of grapes was 3.20 million tonnes in 2014-15 (NCAER, 2016). About 8\% of total production of grapes worth of about Rs. 1,666 crores is exported every year (NRCG,
2015). The fruit is highly perishable in nature, and cannot be stored as such for longer periods under ambient conditions. In India per capita postharvest losses of grapes account for about $8.63 \%$ of production (Jha et al., 2015), which calls for proper preservation and processing facilities in areas where surplus quantities are grown.

Therefore, development of suitable process technology is important through which valueadded products could be prepared from Grapes. Grapes can be transformed into valueadded products such as raisin, wine, juice, 
squash, syrup, jam, jelly, vinegar, pickles, chocolates, tartaric acid, oil, tannin etc. (Oulkar, 2009).

Fruit juices in general are characterized by high acidity conditions, which lead to the growth of yeast and mold, in addition to a few types of low-acid-tolerant bacteria. To avoid microbial spoilage, it is necessary to cause inactivation by applying heat by high temperature heating with very short exposition. Conventional heating processes are based on conduction and convection mechanism, results in very heterogeneous treatment and notable loss of product quality. The major drawbacks of conventional heating are the low energy efficiency and long processing times. To overcome these problems, ohmic heating technology utilizing electrical energy directly in food processing has attracted interests in the food industry in recent decades. Ohmic heating takes its name from Ohm's law; the food material switched between electrodes has a role of resistance in the circuit. Most foods contain a moderate percentage of free water with dissolved ionic salts and therefore conduct sufficiently well for the ohmic effect to be applied (Parrott, 1992).

On the passage of an alternating current through a sample, it responds by generating heat internally due to its inherent resistance (Fryer et al., 1993). This technology provides a rapid and uniform heating and thermal abuse to the product in comparison with conventional heating (Leizerson and Shimoni, 2005). The energy generation is proportional to the square of the local electric field strength (Goullieux and Pain, 2005). It has high energy efficiency because $90 \%$ of electrical energy is converted into heat (De Halleux et al., 2005). Ohmic heating was found to be more efficient for the required microbial and enzymatic inactivation due to a shorter residence time while released flavor compounds were not degraded as quickly as during conventional pasteurization (Leizerson and Shimoni, 2005). Its advantages compared to conventional heating also include the more uniform and faster heating, higher yield and higher retention of nutritional value of food (Vikram et al., 2005). It does not create any noise and is environment friendly (Palaniappan and Sastry, 1991).

The main critical factor in ohmic heating is the electrical conductivity. Electrical conductivity is the measure of how well a substance transmits electrical charge. In ohmic heating terminology, the electrical conductivity is a measure of the mineral or ionic content. It depends on temperature, applied voltage gradient, frequency, and concentration of electrolytes (Icier and Ilicali, 2005b). Therefore, it is very important to determine the electrical conductivity of the food product in the ohmic heating process because it measures the suitability of the product for ohmic heating. Icier and Ilicali (2005a) reported that the electrical conductivity increased linearly with increasing temperatures for orange juices at voltage gradients ranging from 20 to $60 \mathrm{~V} \mathrm{~cm}^{-1}$. Palanippan and Sastry (1991) reported that the electrical conductivity of the orange, carrot and tomato juices increased with temperature and decreased with solids content. Similarly, Icier et al., (2008) found that the electrical conductivity increased as the temperature increased ranging from 0.4 to $0.75 \mathrm{~S} \mathrm{~m}^{-1}$ for fresh grape juice. Amiali et al., (2006) reported that the electrical conductivity $(0.13$ to $0.63 \mathrm{~S} \mathrm{~m}^{-1}$ ) increased linearly with increasing temperatures for fruit juices (namely apple, orange, and pineapple juices). The ohmic heating of fruit juice was studied at different voltage gradients $(7.5$ to $26.25 \mathrm{~V}$ $\mathrm{cm}^{-1}$ ) by Kong et al., (2008). Results indicated that the voltage gradient and temperature significantly influenced the ohmic heating rates. The objective of the present work was to 
obtain electrical conductivity data for grape juice during ohmic heating and to study the effect of temperature and voltage gradients on electrical conductivity of grape juice.

\section{Materials and Methods}

\section{Sample preparation}

Grapes (Vitis vinifera L.) were purchased from a local market in Bapatla, Andhra Pradesh (India) and stored at refrigeration conditions $\left(4{ }^{\circ} \mathrm{C}\right)$ prior to experiments. Berries were manually removed from bunches, washed in cold tap water and drained. The juice was extracted from grapes berries using Sujata Powermatic juicer (Mittal Electronics, Delhi) and filtered with four-fold of new and clean muslin cloth.

\section{Ohmic heating system and procedures}

Experiments were carried out on a lab scale ohmic heating system as shown in Figure 1 with technical specifications as shown in Table 1. The main components of ohmic heating system are - heating chamber, electrodes, power supply and data acquisition system. The heating chamber was made by cylindrical Borosil glass tube of internal diameter $4.5 \mathrm{~cm}$ and length $15 \mathrm{~cm}$. One vertical tubular passage of $1 \mathrm{~cm}$ internal diameter and $3 \mathrm{~cm}$ length was made at the geometric center of heating chamber for removal of water vapour and to hold thermometer. Food grade stainless steel (SS 304) electrodes were secured at both ends of the chamber by anti-leakage rubber plugs. The diameter and thickness of electrodes were 4.4 $\mathrm{cm}$ and $0.2 \mathrm{~cm}$, respectively. A hole of $0.3 \mathrm{~cm}$ was drilled at the center to fasten the electrodes with rubber plugs using screw and nuts. The distance between both electrodes was kept $10 \mathrm{~cm}$ resulting in a total chamber volume of $159 \mathrm{~mL}$. The desired voltage gradient between the electrodes was obtained using a variable auto transformer (Sun Electrical Industries, Thane) of capacity (input-220 V, output-400 V) by supplying the power from domestic alternating current (AC) mains $(220 \mathrm{~V}, 50 \mathrm{~Hz})$. Temperature was continuously measured with the mercury thermometer. Current and voltage were measured with analog ammeter (Meco Instruments, India) ranging 0-15 amp and analog voltmeter (KEC, India) ranging 0-500 $\mathrm{V}$, respectively.

The $150 \mathrm{~mL}$ of filtered grape juice sample was placed in the heating chamber, the thermometer was inserted. The electric current was supplied from domestic AC mains. Voltage gradient between electrodes for particular treatment was maintained with variable auto transformer by moving knob. The juice was heated at different combinations of $10 \mathrm{~V} \mathrm{~cm}^{-1}, 20 \mathrm{~V} \mathrm{~cm}^{-1}, 30 \mathrm{~V} \mathrm{~cm}^{-1}$ and $40 \mathrm{~V}$ $\mathrm{cm}^{-1}$ by holding at $55{ }^{\circ} \mathrm{C}, 65{ }^{\circ} \mathrm{C}, 75{ }^{\circ} \mathrm{C}$ and 85 ${ }^{\circ} \mathrm{C}$. Temperature, current and voltage applied were monitored.

\section{Electrical conductivity of grape juice}

Electrical conductivity of the grape juice samples was calculated using the following equation (Icier et al., 2008)

$\sigma=\frac{\mathrm{LI}}{\mathrm{AV}}(1)$

Where,

$\sigma=$ Electrical conductivity of the sample $\left(\mathrm{S} \mathrm{m}^{-1}\right)$

$\mathrm{L}=$ Space between electrodes or the length of the ohmic chamber $(\mathrm{m})$

$\mathrm{A}=$ Heating surface area of the electrodes $\left(\mathrm{m}^{2}\right)$

$I=$ Electrical current passing through the sample (amp) 
$\mathrm{V}=$ Voltage applied between electrodes $(\mathrm{V})$ Accuracy

The accuracy of ohmic system was compared and calibrated with the standard conductivity. The calibration results for the accuracy of electrical conductivity of $0.1 \mathrm{M} \mathrm{NaCl}$ solution revealed that there was no significant difference between standard electrical conductivity of $0.1 \mathrm{M} \mathrm{NaCl}$ solution and the experiment data. The electrodes were thoroughly rinsed using a brush and dematerialized with twice-distilled water after each run.

\section{Statistical analysis}

The effect of voltage gradient and heating temperature on electrical conductivity were statistically analyzed for analysis of variance (ANOVA) by using Statistical Package for Social Sciences (SPSS) version SPSS 16.0 at the 5 per cent level of significance i.e. $p<0.05$ (SPSS, 2008). The results were reported as an average of three replicates.

\section{Results and Discussion}

Results of the analysis of covariance are shown in Table 2. The results indicated that the voltage gradient and temperature had significant effect on the electrical conductivity value of grape juice $(\mathrm{p}<0.05)$.

\section{Effect of voltage gradient on electrical conductivity of grape juice}

Electrical conductivity of grape juice samples observed were $0.25-0.81 \mathrm{~S} \mathrm{~m}^{-1}$ at $10-40 \mathrm{~V}$ $\mathrm{cm}^{-1}$ and $30-85^{\circ} \mathrm{C}$. Icier et al., (2008) reported conductivity of grape juice, $0.38-0.78 \mathrm{~S} \mathrm{~m}^{-1}$ at voltage gradient $20-40 \mathrm{~V} \mathrm{~cm}^{-1}$ and temperature 20-80 ${ }^{\circ} \mathrm{C}$. The observed difference between the data presented here and earlier data could be attributed to the natural variation occurring in biological tissues and difference in voltage gradient and heating temperature range. The value of electrical conductivity of grape juice in this study is comparable with the reported values; $0.1-1.6 \mathrm{~S} \mathrm{~m}^{-1}$ for apple and sour cherry juices at $20-60 \mathrm{~V} \mathrm{~cm}^{-1}$ and $30-75^{\circ} \mathrm{C}$ (Icier and Ilicali., 2004) and 0.4-1.0 S m${ }^{-1}$ for lemon juice at $30-55 \mathrm{~V} \mathrm{~cm}^{-1}$ and $20-74{ }^{\circ} \mathrm{C}$ (Darvishi et al., 2011).

The lowest electrical conductivity observed was $0.25 \mathrm{~S} \mathrm{~m}^{-1}$ at $10 \mathrm{~V} \mathrm{~cm}^{-1}$ and the highest was $0.81 \mathrm{~S} \mathrm{~m}^{-1}$ at $30 \mathrm{~V} \mathrm{~cm}^{-1}$. Figure 2 shows changes in electrical conductivity as voltage gradient increased. Electrical conductivity initially increased with voltage gradient from $10-30 \mathrm{~V} \mathrm{~cm}^{-1}$ and then decreased at $40 \mathrm{~V} \mathrm{~cm}^{-1}$. Electrical conductivity at $40 \mathrm{~V} \mathrm{~cm}^{-1}$ was found to be $0.78 \mathrm{~S} \mathrm{~m}^{-1}$. At this voltage gradient formation of bubbles was observed, especially when the temperature of samples reached above $75{ }^{\circ} \mathrm{C}$. It was observed that as the voltage gradients increased, the current passing through the system reached higher values and this caused violent evaporation of water in the samples and increase in electrical conductivity become slower due to bubble formation. Similar opinion was put forth by Icier and Ilicali (2004) for apple and sourcherry juice. It was felt that the bubbling could be the release of gas in the liquid due to some electro-chemical reactions. Darvishi et al., (2013) concluded similar reason for bubbling at $55 \mathrm{~V} \mathrm{~cm}^{-1}$ and $81{ }^{\circ} \mathrm{C}$ in pomegranate juice.

Effect of temperature on the electrical conductivity of grape juice

The highest value of the electrical conductivity of grape juice was observed to be $0.81 \mathrm{~S} \mathrm{~m}^{-1}$ at $85^{\circ} \mathrm{C}$ temperature. As shown in Figure 2, the electrical conductivity of the grape juice increased with temperature at all voltage gradients studied. It was felt that this may be due to reduced drag for the movement of ions. 
Fig.1 Developed ohmic heating system

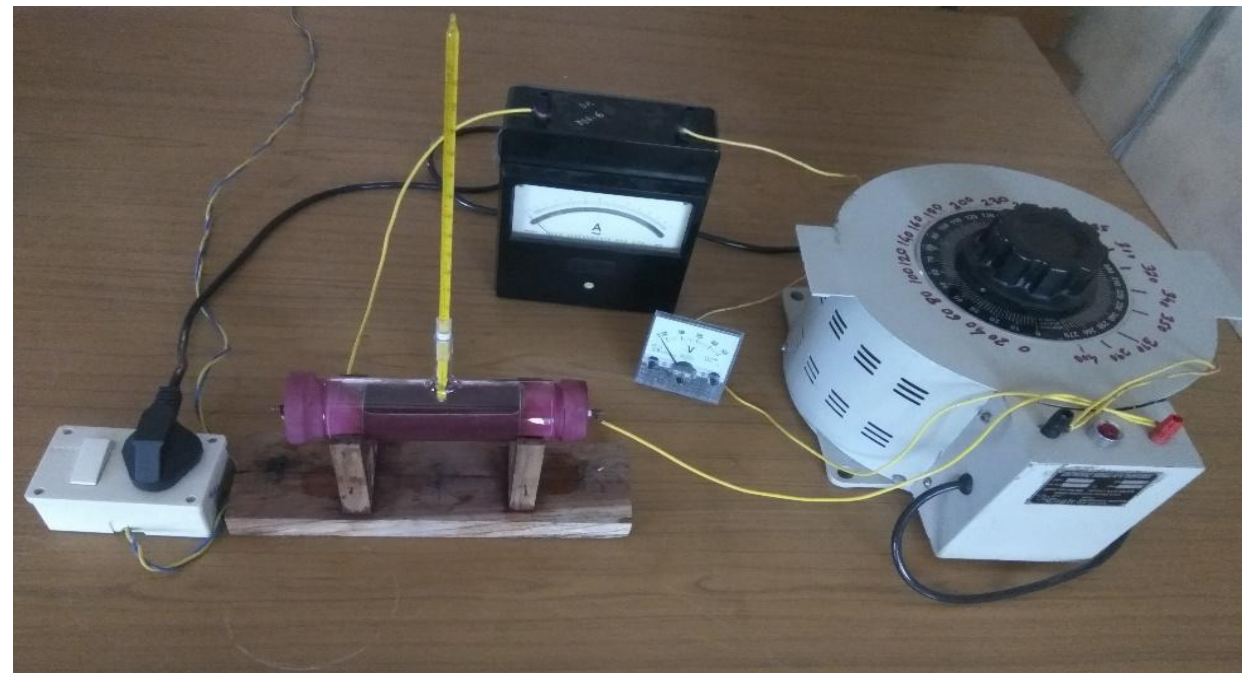

Fig.2 Changes in electrical conductivity of grape juice with temperature at different voltage gradients

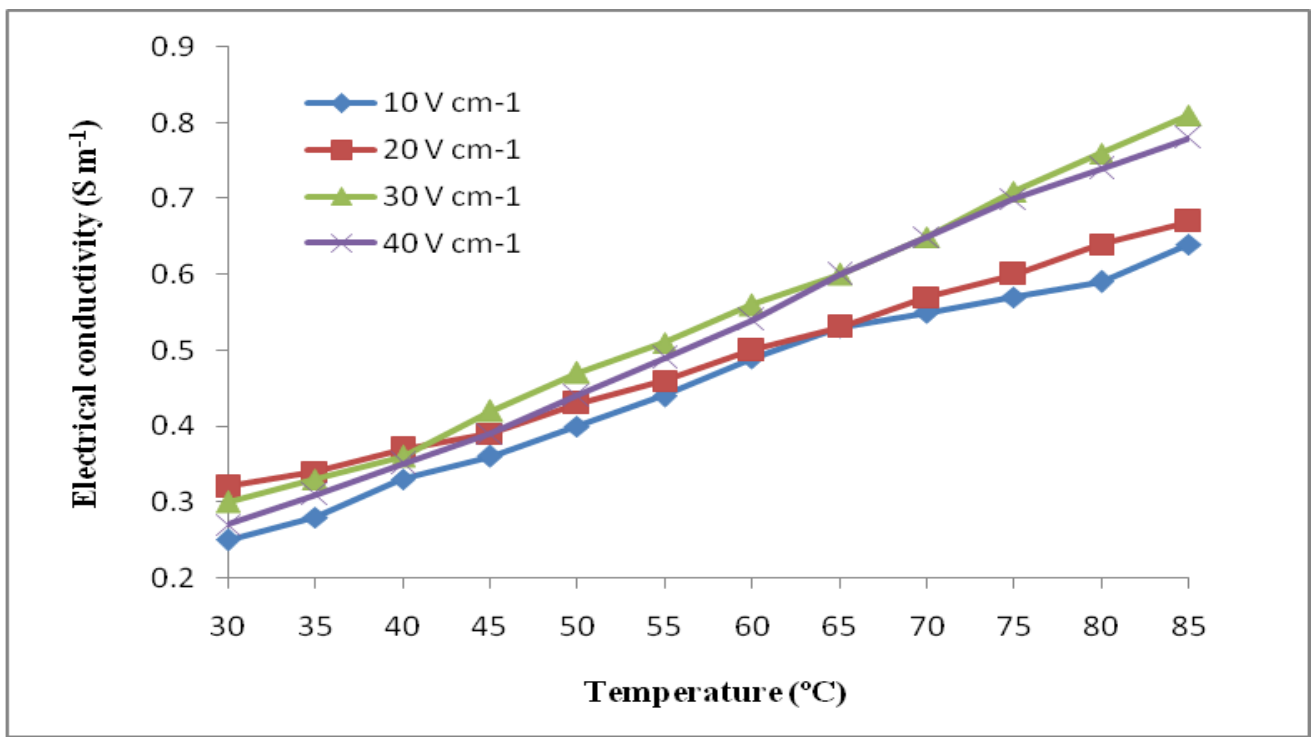

\section{List of Abbreviation}

\begin{tabular}{|l|l|}
\hline ANOVA & Analysis of variance \\
\hline et al., & And others people \\
\hline NCAER & National Council of Applied Economic Research \\
\hline NRCG & National Research Centre for Grapes \\
\hline Rs. & Rupees \\
\hline SPSS & Statistical Package for Social Sciences \\
\hline SS & Stainless steel \\
\hline
\end{tabular}


Table.1 Technical specifications of the ohmic heating system

\begin{tabular}{|c|c|c|}
\hline Component & \multicolumn{2}{|l|}{ Specification } \\
\hline \multirow{3}{*}{$\begin{array}{l}\text { Ohmic heating } \\
\text { chamber }\end{array}$} & Material & Borosil glass \\
\hline & Diameter $\times$ length, $\mathrm{cm}$ & $4.5 \times 15$ \\
\hline & Capacity, mL & 159 \\
\hline \multirow{4}{*}{ Electrode } & Material & SS 304 \\
\hline & Diameterxthickness, $\mathrm{cm}$ & $4.4 \times 0.2$ \\
\hline & Heating surface area, $\mathrm{cm}^{2}$ & 15.21 \\
\hline & Distance between electrodes, $\mathrm{cm}$ & 10 \\
\hline \multirow{2}{*}{$\begin{array}{l}\text { Variable } \\
\text { autotransformer }\end{array}$} & Input & $220 \mathrm{~V}, 50 \mathrm{~Hz}$ \\
\hline & Output & $400 \mathrm{~V}, 50 \mathrm{~Hz}$ \\
\hline Voltmeter & $0-500 \mathrm{~V}$ & \\
\hline Ammeter & $0-15 \mathrm{amp}$ & \\
\hline Thermometer & $0-100{ }^{\circ} \mathrm{C}$ & \\
\hline
\end{tabular}

Table.2 Analysis of variance table for electrical conductivity of grape juice

\begin{tabular}{|l|l|l|l|l|l|}
\hline Source & Type III Sum of Squares & df & Mean Square & F & Sig. \\
\hline Corrected Model & $1.294^{\mathrm{a}}$ & 18 & .072 & 71.785 & .000 \\
\hline Intercept & 16.724 & 1 & 16.724 & $1.670 \mathrm{E} 4$ & .000 \\
\hline Voltage gradient (V) & .105 & 3 & .035 & 35.096 & .000 \\
\hline Temperature (T) & 1.060 & 4 & .265 & 264.575 & .000 \\
\hline V×T & .033 & 11 & .003 & 3.018 & .006 \\
\hline Error & .038 & 38 & .001 & & \\
\hline Total & 18.785 & 57 & & & \\
\hline Corrected Total & 1.332 & 56 & & & \\
\hline${ }^{a} \mathrm{R}^{2}=.971$ (Adjusted $\left.\mathrm{R}^{2}=.958\right)$ & & & & \\
\hline
\end{tabular}

This phenomenon occurs because of structural changes in the tissue like cell wall breakdown and lowering in viscosity and thus increases in the ionic mobility. Similar result was reported by Icier and Ilicali (2005a) in orange juice; Icier et al., (2008) in grape juice and Darvishi et al., (2011) in lemon juice.

It can be concluded that the electrical conductivity of grape juice was strongly dependent on voltage gradient and temperature. The voltage gradient was statistically significant on electrical conductivity grape juice. In all cases considered the electrical conductivity increased linearly with temperature. The rate of change of the electrical conductivity of grape juice with temperature for $30 \mathrm{~V} \mathrm{~cm}^{-1}$ at $85^{\circ} \mathrm{C}$ was higher as compared to other voltage gradients applied. The results of the present work can be used industrially to determine processing effectiveness when ohmic heating technology is applied.

\section{Acknowledgment}

The authors are grateful to College of Agricultural Engineering, Bapatla, and 
College of Food Science and Technology, Bapatla, ANGRAU, Guntur, Andhra Pradesh for providing necessary facilities to carry out the present study.

\section{References}

Amiali, M., M. O. Ngadi, V. G. S. Raghavan and Nguyen, D. H. 2006. Electrical conductivities of liquid egg product and fruit juices exposed to high pulsed electric fields. International Journal of Food Properties, 9(3): 533-540.

Darvishi, H., A. Hosainpour, F. Nargesi, M. H. Khoshtaghza and Torang H. 2011. Ohmic processing: temperature dependent electrical conductivities of lemon juice. Modern Applied Science. 5(1): 210-216.

Darvishi, H., M. H. Khostaghaza and Najafi, G. 2013. Ohmic heating of pomegranate juice: Electrical conductivity and $\mathrm{pH}$ change. Journal of the Saudi Society of Agricultural Sciences. 12(2): 101-108.

De Halleux D., G. Piette, M. L. Buteau and Dostie M. 2005. Ohmic cooking of processed meats: Energy evaluation and food safety considerations. Canadian Biosystems Engineering 47: 3.41-3.47.

Fryer, P. J., A. A. P. de Alwis, E. Koury, A. G. F. Stapley and Zhang, L. 1993. Ohmic processing of solid-liquid mixtures: heat generation and convection effects. Journal of Food Engineering. 18(2): 101-125.

Goullieux, A., and Pain, J. P. 2005. Ohmic Heating. In Sun, D.W. (Ed.), Emerging Technologies for Food Processing, Elsevier Academic Press, London. 469-505.

Icier, F., and Ilicali, C. 2004. Electrical conductivity of apple and sourcherry juice concentrates duringohmic heating. Journal of Food Process Engineering. 27(3): 159-180.
Icier, F., and Ilicali, C. 2005a. The effects of concentration on electrical conductivity of orange juice concentrates during ohmic heating. European Food Research and Technology. 220(3): 406414.

Icier, F., and Ilicali, C. 2005b. Temperature dependent electrical conductivities of fruit purees during ohmic heating. Food Research International. 38(10): 11351142.

Icier, F., H. Yildiz and Baysal, T. 2008. Polyphenoloxidase deactivation kinetics during ohmic heatingof grape juice. Journal of Food Engineering. 85(3): 410-417.

Jha S. N., R. K. Vishwakarma, T. Ahmad, A. Rai and Dixit A. K. 2015. Report on assessment of quantitative harvest and post-harvest losses of major crops and commodities in India. ICAR-All India Coordinated Research Project on PostHarvest Technology, ICAR-CIPHET, Ludhiana.

Kong, Y. Q., D. Li, L. J. Wang, B. Bhandari, X. D. Chen and Mao, J. H. 2008. Ohmic heating behavior of certain selected liquid food materials. International Journal of Food Engineering. 4(3): 113.

Leizerson, S., and Shimoni, E. 2005b. Stability and sensory shelf life of orange juice pasteurized by continuous ohmic heating. Journal of Agricultural and Food Chemistry. 53(10): 4012-4018.

NCAER. 2016. Agricultural Outlook and Situation Analysis Reports: Rabi Outlook Report. National Council of Applied Economic Research, New Delhi. January 2016. 91.

NRCG. 2015. Vision-2050. Indian Council of Agricultural Research-National Research Centre for Grapes, Pune. July 2015. 3.

Oulkar D. P. 2009. Metabolic fate of contaminant residues in grapes at 
various stages of processing to raisins and wines. Ph. D. Thesis. Shivaji University, Kolhapur, Maharashtra, India. 224.

Palaniappan, S., and Sastry, S. K. 1991. Electrical conductivities of selected solid foods during ohmic heating. Journal of Food Process Engineering. 14(3): 221-236.

Parrott D. L. 1992. Use of ohmic heating for aseptic processing of food particulates. Food Technology, 46, 68-72

Rolle, L., S. Giacosa and Gerbi, V. 2011. Comparative study of texture properties, color characteristics and chemical composition of ten white table grape varieties. American Journal of Enology and Viticulture. 62: 49-56.

SPSS. 2008. Statistical Package for Social Sciences. Version SPSS 16.0. SPSS Incorporation, Chicago, IL, USA.

Vikram, V. B., M. N. Ramesh and Prapulla S. G. 2005. Thermal degradation kinetics of nutrients in orange juice heated by electromagnetic and conventional methods. Journal of Food Engineering. 69(1): 31-40.

\section{How to cite this article:}

Tankesh Kumar, D.D. Smith, Sivala Kumar and Vimla, B. 2018. Effect of Voltage Gradient and Temperature on Electrical Conductivity of Grape (Vitis vinifera L.) Juice during Ohmic Heating. Int.J.Curr.Microbiol.App.Sci. 7(05): 1914-1921. doi: https://doi.org/10.20546/ijcmas.2018.705.224 